\title{
Ground-Water Quality in Islamkot and Mithi Talukas of District Tharparkar, Sindh, Pakistan
}

\author{
JHAMAN DAS SUTHAR*, INAYATULLAH RAJPER*, ZIA-UL-HASSAN*, NIZAMUDDIN DEPAR**, \\ AND VELO SUTHAR***
}

\section{RECEIVED ON 20.12.2017 ACCEPTED ON 12.02.2018}

\begin{abstract}
Surface water supplies are gradually becoming short in arid and semi-arid regions of the world. Thus, assessment of groundwater quality for crop use appears to be very essential for management and utilization of precious natural water resources. This study reports the water quality of 52 hand pumps and one tubewell located in the most remote areas of desert region, viz. Islamkot and Mithi talukas of district Tharparkar. The water samples were collected during April 2016 (just before the start of rainy season). The water samples were analyzed for $\mathrm{EC}$ (Electrical Conductivity), $\mathrm{pH}, \mathrm{CO}_{3}^{2-}, \mathrm{HCO}_{3}^{-}, \mathrm{Cl}, \mathrm{Ca}^{2+}, \mathrm{Mg}^{2+}$ and $\mathrm{Na}^{+}$concentration. The SAR (Sodium Adsorption Ratio) and RSC (Residual Sodium Carbonates) were estimated using their respective formula. The categorization of water samples based on their soluble salt content clearly revealed that the water bodies of majority $(65 \%)$ of areas were hazardous, while $25 \%$ areas were marginal. Thus, only $11 \%$ water samples of the area under study had useable irrigation water. Because of SAR and RSC the majority ( 89 and $77 \%$, respectively) of water samples were found to be free from the sodicity hazard. The study concluded that salinity, and not sodicity was the major threat to the area under irrigation with these water bodies. It is, therefore, suggested that the salinity tolerant crops and their genotypes may be used in this area to sustain crop production.
\end{abstract}

Key Words: Groundwater Quality, Desert Area, Tharparkar

\section{INTRODUCTION}

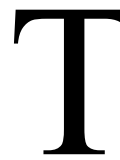

harparkar is a southern district of Sindh province, Pakistan. The climatic condition of the district is mostly arid and semi-arid; having average annual rainfall less than $125 \mathrm{~mm}$. Fresh water resources in this area are limited, even for drinking purpose. However, agricultural crops are totally dependent upon precipitation. The uneven amount and distribution of rainfall further worsen the situation and dependent nature of the area. Because of this problem, wise management practices and other resource like groundwater can be used for irrigation purpose according to its quality criteria [1]. Almost all waters containment with salts; however, the quality of water depends on the composition and concentration of ions present in it [2-3]. It is very much

Authors E-Mail: (jhaman@gmail.com, irajpar@yahoo.com, zhnshah@gmail.com, ndepar@gmail.com, vsutahar@yahoo.co.uk) Department of Soil Science, Sindh Agriculture University, Tando Jam, Pakistan.

** Soil \& Environmental Division, Nuclear Institute of Agriculture, Tando Jam, Pakistan.

*** Department of Statistics, Sindh Agriculture University, Tando Jam, Pakistan.

This is an open access article published by Mehran University Research Journal of Engineering and Technology, Jamshoro under the CC by 4.0 International License. 
critical to recognize the changes in strategies of water suitability for long term productivity of crops [4]. Quality of ground water has been assessed by different scientists in Tharparkar district. They reported that the water samples were saline and sodium hazardous [5-6]. It has been reported that the low quality of groundwater of Pakistan mainly due to available or more soluble salt within it [7]. According to the recent studies, the ground water contains high concentration of soluble salts and sodium ions that are used for irrigation purpose cause soil salinity or soil sodicity [8]. Whereas some water is suitable for irrigation purpose if it contains salt below the hazardous level [9]. This study assesses quality of ground water according to the usability for indigenous crops of the area.

\section{MATERIALS AND METHOD}

\subsection{Water Sampling}

Populous villages of two taluka of district Tharparkar, i.e. Mithi and Islamkot, were selected for this study. From the selected 53 locations ( 25 of Mithi Taluka and 28 of Islamkot Taluka), sampling of ground water from 52 hand pumps and 1 Tube well (Khario Nara) were collected and analyzed through the suggested methods [10]. The depth of water pumps were also noted (Table 1), which was in the range of 18.3-76.2m. Collected samples were transported to the laboratory of bio-saline, Department of Soil Science, Sindh Agriculture University, Tandojam, Pakistan, for further analysis.

\subsection{Water Analysis}

Collected water samples were analyzed following the suggested protocol [11], for $\mathrm{EC}_{\mathrm{iw}}$ through standardized digital EC meter (Cyber Scan CON 11, Singapore) and pH using digital pH meter (Lavibond pH1 10, Singapore). Different soluble including $\mathrm{Na}^{+}$were analyzed using flame photo meter; whereas total $\mathrm{Ca}^{2+}$ and $\left(\mathrm{Ca}^{2+}+\mathrm{Mg}^{2+}\right)$ were determined through complex metric titration with EDTA (Ethylene Diamine Tetra Acetic Acid) solution, using $2-3 \mathrm{~mL}$ of $2 \mathrm{~N} \mathrm{NaOH}$ solution and about $50 \mathrm{mg}$ ammonium purpurate as an indicator for calcium and 3$5 \mathrm{~mL}$ buffer solution $\left(\mathrm{NH}_{4} \mathrm{Cl}-\mathrm{NH}_{4} \mathrm{OH}\right)$ and few drops of Eriochromeblack- $\mathrm{T}$ as an indicator for calcium plus magnesium. Whereas for anion like $\mathrm{CO}_{3}{ }^{2-}, 1 \mathrm{ml}$ phenolphthalein indicator $(1 \%)$ was added to measured amount of water sample. If its colour becomes pink, it indicates the presence of carbonates. Methyl orange indicator $0.1 \%$ was used for determination of $\mathrm{HCO}_{3}^{-}$. $\mathrm{H}_{2} \mathrm{SO}_{4}(0.01 \mathrm{~N})$ was used for titration in the case of carbonates and bicarbonate analysis. Whereas chlorides were analyzed through $0.005 \mathrm{~N} \mathrm{AgNO}_{3}$ (Mohrs's titration) using potassium chromate $\left(\mathrm{K}_{2} \mathrm{CrO}_{4}\right) 5 \%$ as an indicator.

SAR [12] and RSC [12-13] were calculated with the formulas give below:

$\mathrm{SAR}=\mathrm{Na}^{+} /\left[\left(\mathrm{Ca}^{2+}+\mathrm{Mg}^{2+}\right) / 2\right]^{0.5}$

$\operatorname{RSC}\left(\right.$ meq L $\left.{ }^{-1}\right)=\left[\left(\mathrm{CO}_{3}^{2-}+\mathrm{HCO}_{3}^{-}\right)-\left(\mathrm{Ca}^{2+}+\mathrm{Mg}^{2+}\right)\right]$

TABLE 1. WATER QUALITY CRITERIA BASED ON EC ${ }_{\text {IW }}$, SAR AND RSC

\begin{tabular}{|c|c|c|c|c|}
\hline No. & Classification & $\begin{array}{c}\text { ECiw } \\
(\mathrm{dS} m-1)\end{array}$ & SAR & RSC \\
\hline 1. & Useable C1S1R1 & $<1.5(\mathrm{C} 1)$ & $<10(\mathrm{~S} 1)$ & $<2.5(\mathrm{R} 1)$ \\
\hline 2. & Marginal C2S2R2 & $1.5-3.0(\mathrm{C} 2)$ & $10-18(\mathrm{~S} 2)$ & $2.5-5.0(\mathrm{R} 2)$ \\
\hline 3. & Hazardous C3S3R3 & $>3(\mathrm{C} 3)$ & $>18(\mathrm{~S} 3)$ & $>5(\mathrm{R} 3)$ \\
\hline
\end{tabular}

Mehran University Research Journal of Engineering \& Technology, Volume 38, No. 1, January, 2019 [p-ISSN: 0254-7821, e-ISSN: 2413-7219] 


\subsection{Water Quality Classification}

Irrigation water quality is classified based on salinity and sodium hazard (SAR and RSC) to the plant growth and development. Critical limits for these criteria are mentioned in Table 1 [14].

\subsection{Statistical Analysis}

The data were statistically analyzed for minimum value, maximum value, mean, mode standard deviation and coefficient variance using Microsoft Excel [15]

\section{RESULTS AND DISCUSSION}

\subsection{Chemical Composition and Properties of Groundwater}

There are some specific quality parameters of groundwater related to the managing irrigation for better crop production. Parameters including $\mathrm{EC}_{\mathrm{iw}}, \mathrm{pH}$, different ions, SAR and RSC were used to evaluate the water quality for irrigation purposes $[14,16]$.

\subsubsection{Electrical Conductivity}

EC is the measurement of conductance in water. The conductance increases with increasing salt concentration in water [17]. The data reported in Table 2 shows that $\mathrm{EC}_{\mathrm{iw}}$ of groundwater ranges from $0.3-13.5 \mathrm{dS} \mathrm{m}^{-1}$ and $38 \%$ of samples recoded (Table 3 ) above the mean $\left(4.9 \mathrm{dS} \mathrm{m}^{-1}\right)$ value. According to classification [14], groundwater containing $\mathrm{EC}_{\mathrm{iw}}$ values less than $1.5 \mathrm{dS} \mathrm{m}^{-1}$ have been considered as useable, whereas in the range of 1.5-3 dS $\mathrm{m}^{-1}$ as marginal and more than $3 \mathrm{dS} \mathrm{m}^{1}$ considered as hazardous for irrigating the crops.

\subsection{2 pH}

The $\mathrm{pH}$ indicates the acidity and alkalinity of groundwater and the normal range of $\mathrm{pH}$ is $6.5-8.4$ for irrigation water
[16]. Out of collected 53 groundwater samples $54.7 \%$ fall in the normal range and others were above that normal limit. The $\mathrm{pH}$ value recorded of groundwater samples were varied from 7.3-9.0 (Table 2) and mean value (8.06) was in the normal range.

\subsubsection{Sodium Adsorption Ratio}

The quality of irrigation water mainly depends upon the salinity and sodicity parameters. SAR is the measurement of potential hazardous of $\mathrm{Na}^{+}$over the $\mathrm{Ca}^{2+}$ and $\mathrm{Mg}^{2+}$. The SAR values are mostly used for predicting the accumulation of $\mathrm{Na}^{+}$in soil that causes the sodicity problem [18]. The minimum SAR (4.0) and maximum SAR (15.5) and mean (7.4) values were recorded (Table 2) of groundwater samples.

\subsubsection{Residual Sodium Carbonates}

$\mathrm{RSC}$ is the excess value of $\mathrm{Ca}^{2+}+\mathrm{Mg}^{2+}$ as of $\mathrm{CO}_{3}{ }^{2-}+\mathrm{HCO}_{3}$, that effects the quality of irrigation water [19]. The collected samples of groundwater had value of RSC as recorded in Tables 2-3 aranging from -7.08-8.4 with average value (0.74). A negative RSC value indicates low sodium hazardous, whereas positive value shows high risk and accumulation of $\mathrm{Na}^{+}$on soil sites with releasing of $\mathrm{Ca}^{2+}$ and $\mathrm{Mg}^{2+}[20]$.

\subsection{Categorization of Water Samples}

Groundwater water samples were categorized [14] in different classes (Table 1), based on three parameters $\mathrm{EC}_{\mathrm{iw}}$ (C), SAR (S) and RSC (R), each parameter divided into useable, marginal and hazardous.

As per classification [14], EC values 11, 25 and 64\%, SAR values 89,11 and $0 \%$ and as of RSC values 77,19 and $4 \%$ groundwater samples fall in the categories of useable, marginal and hazardous respectively (Fig. 1). 
TABLE 2. NAME OF SITES, DEPTH, EC ${ }_{\text {IW }}$ AND PH, SAR, RSC AND CLASSES WITH DESCRIPTIVE STATISTICS OF WATER BODIES OF STUDY AREA OF TALUKA MITHI AND ISLAMKOT

\begin{tabular}{|c|c|c|c|c|c|c|c|}
\hline Site No. & Name of Village & $\begin{array}{c}\text { Depth } \\
\text { (m) }\end{array}$ & $\begin{array}{l}\text { ECiw } \\
\mathrm{dS} / \mathrm{m}\end{array}$ & $\mathrm{pH}$ & SAR & $\mathrm{RSC}$ & Classes \\
\hline 1. & Mithi-1 & 51.8 & 11.1 & 8.7 & 8.1 & -5.39 & $\overline{\mathrm{C} 3 \mathrm{~S} 1 \mathrm{R} 1}$ \\
\hline 2. & Mithi-2 & 54.9 & 11.4 & 8.7 & 7.1 & 2.01 & $\overline{\mathrm{C} 3 \mathrm{~S} 1 \mathrm{R} 1}$ \\
\hline 3. & Mithi-3 & 54.9 & 11.1 & 8.6 & 5.2 & 1.93 & $\overline{\mathrm{C} 3 \mathrm{~S} 1 \mathrm{R} 1}$ \\
\hline 4. & Mithi-4 & 53.3 & 9.7 & 8.7 & 8.8 & 1.15 & $\overline{\mathrm{C} 3 \mathrm{~S} 1 \mathrm{R} 1}$ \\
\hline 5 . & Pabuhar-1 & 39.6 & 2.9 & 7.3 & 4.4 & -7.08 & $\overline{\mathrm{C} 2 \mathrm{~S} 1 \mathrm{R} 1}$ \\
\hline 6. & Pabuhar-2 & 41.1 & 9.2 & 8.0 & 9.2 & 0.01 & $\overline{\mathrm{C} 3 \mathrm{~S} 1 \mathrm{R} 1}$ \\
\hline 7. & Kakjuneja & 54.9 & 9.1 & 8.0 & 7.5 & 2.74 & $\overline{\mathrm{C} 3 \mathrm{~S} 1 \mathrm{R} 2}$ \\
\hline 8. & Malanhore Khanji-1 & 62.5 & 3.4 & 8.0 & 4.4 & -1.85 & $\overline{\mathrm{C} 3 \mathrm{~S} 1 \mathrm{R} 1}$ \\
\hline 9. & Malanhore Khanji-2 & 51.8 & 5.4 & 8.0 & 5.3 & -4.55 & C3S1R \\
\hline 10. & Hemasar-1 & 61.0 & 2.5 & 8.0 & 4.2 & 0.30 & C2S1R \\
\hline 11. & Hemasar-2 & 51.8 & 3.5 & 8.0 & 5.4 & -1.23 & C3S1R1 \\
\hline 12. & Hemasar-3 & 53.3 & 5.0 & 8.0 & 4.7 & -1.44 & C3S1R1 \\
\hline 13. & Hothiar & 50.3 & 10.3 & 8.0 & 8.4 & 0.48 & C3S1R \\
\hline 14. & SaatarKolhi & 57.9 & 1.5 & 8.3 & 13.0 & 3.48 & $\mathrm{C} 1 \mathrm{~S} 2 \mathrm{R} 2$ \\
\hline 15. & Tabho Menghwar-1 & 61.0 & 4.4 & 8.5 & 5.5 & 2.12 & C3S1R1 \\
\hline 16. & Tabho Menghwar-2 & 62.5 & 5.6 & 7.9 & 5.7 & 1.30 & C3S1R1 \\
\hline 17. & Abdulah-Ji-Dhani & 39.6 & 7.6 & 8.6 & 5.8 & 1.89 & C3S1R 1 \\
\hline 18. & Pabe Jo Tar & 67.1 & 5.5 & 8.1 & 6.7 & 3.46 & $\overline{\mathrm{C} 3 \mathrm{~S} 1 \mathrm{R} 2}$ \\
\hline 19. & Mithario Bhatti-1 & 68.6 & 3.2 & 7.9 & 10.9 & 2.29 & C3S2R1 \\
\hline 20. & Mithario Bhatti-2 & 73.2 & 3.2 & 8.0 & 7.6 & 0.63 & C3S1R \\
\hline 21. & MitharioBheel & 41.1 & 4.6 & 7.3 & 8.9 & 0.03 & C3S1R1 \\
\hline 22. & Bhope Jo Tar & 53.3 & 3.3 & 7.8 & 5.8 & 2.32 & C3S1R 1 \\
\hline 23. & Bughar & 57.9 & 4.2 & 8.6 & 7.5 & 6.24 & C3S1R. \\
\hline 24. & Nauhonto & 30.5 & 0.3 & 7.7 & 6.8 & 1.67 & C1S1R1 \\
\hline 25. & Khario Nara & 76.2 & 9.1 & 7.5 & 7.2 & 2.20 & $\overline{\mathrm{C} 3 \mathrm{~S} 1 \mathrm{R} 2}$ \\
\hline 26. & Borli M-1 & 45.7 & 1.8 & 7.4 & 6.7 & -0.14 & $\overline{\mathrm{C} 2 \mathrm{~S} 1 \mathrm{R} 1}$ \\
\hline 27. & Borli M-2 & 48.8 & 5.1 & 8.0 & 15.5 & -0.05 & C3S2R1 \\
\hline 28. & Wadhan & 24.4 & 1.2 & 8.0 & 13.0 & -0.70 & $\overline{\mathrm{C} 1 \mathrm{~S} 2 \mathrm{R} 1}$ \\
\hline 29. & Ghoralsio & 25.9 & 1.0 & 8.0 & 8.8 & -0.39 & $\overline{\mathrm{C} 1 \mathrm{~S} 1 \mathrm{R} 1}$ \\
\hline 30. & Aakali & 27.4 & 1.1 & 9.0 & 7.4 & 0.30 & C1S1R1 \\
\hline 31. & Doonjh-1 & 27.4 & 4.5 & 8.0 & 11.7 & -3.87 & $\overline{\mathrm{C} 3 \mathrm{~S} 2 \mathrm{R} 1}$ \\
\hline 32. & Doonjh-2 & 25.9 & 2.6 & 8.0 & 8.5 & 0.71 & $\overline{\mathrm{C} 2 \mathrm{~S} 1 \mathrm{R} 1}$ \\
\hline 33. & ShurabWasaipota & 39.6 & 3.0 & 8.0 & 9.2 & -0.80 & $\mathrm{C} 2 \mathrm{~S} 1 \mathrm{R} 1$ \\
\hline 34. & Khankhanyar-B & 48.8 & 0.9 & 8.0 & 4.3 & 0.05 & $\overline{\mathrm{C} 1 \mathrm{~S} 1 \mathrm{R} 1}$ \\
\hline 35. & LakhiTobho & 33.5 & 2.7 & 8.0 & 5.2 & -3.54 & C2S1R1 \\
\hline 36. & DabhoNajar & 30.5 & 5.3 & 8.0 & 6.2 & 2.71 & $\overline{\mathrm{C} 3 \mathrm{~S} 1 \mathrm{R} 2}$ \\
\hline 37. & MisriMemon & 61.0 & 3.9 & 7.3 & 6.4 & 1.51 & C3S1R 1 \\
\hline 38. & Siranghoo & 54.9 & 2.2 & 8.1 & 5.3 & 0.03 & $\mathrm{C} 2 \mathrm{~S} 1 \mathrm{R} 1$ \\
\hline 39. & Warvai & 56.4 & 2.6 & 7.9 & 6.4 & -0.47 & $\overline{\mathrm{C} 2 \mathrm{~S} 1 \mathrm{R} 1}$ \\
\hline 40. & MitharaooChhuto & 48.8 & 2.7 & 7.8 & 7.8 & -1.17 & $\overline{\mathrm{C} 2 \mathrm{~S} 1 \mathrm{R} 1}$ \\
\hline 41. & Nau-Tar & 51.8 & 7.7 & 7.3 & 7.3 & -1.81 & C3S1R1 \\
\hline 42. & Nikno & 54.9 & 13.5 & 8.7 & 8.5 & 2.01 & $\overline{C 3 S 1 R 1}$ \\
\hline 43. & Areri & 18.3 & 1.7 & 8.6 & 6.4 & 8.40 & $\mathrm{C} 2 \mathrm{~S} 1 \mathrm{R} 3$ \\
\hline 44. & VeeHingorja & 51.8 & 2.1 & 7.9 & 5.2 & 0.81 & $\mathrm{C} 2 \mathrm{~S} 1 \mathrm{R} 1$ \\
\hline 45. & Bhatian Je Veri & 30.5 & 8.5 & 8.3 & 6.7 & 4.23 & $\mathrm{C} 3 \mathrm{~S} 1 \mathrm{R} 2$ \\
\hline 46. & Joglahar & 53.3 & 8.5 & 8.6 & 7.3 & 4.32 & $\mathrm{C} 3 \mathrm{~S} 1 \mathrm{R} 2$ \\
\hline 47. & Joglahar & 57.9 & 2.1 & 8.3 & 11.6 & 4.00 & $\mathrm{C} 2 \mathrm{~S} 2 \mathrm{R} 2$ \\
\hline 48. & BoriliTarai & 48.8 & 1.6 & 8.2 & 8.1 & 1.79 & $\overline{\mathrm{C} 2 \mathrm{~S} 1 \mathrm{R} 1}$ \\
\hline 49. & JogiMarhi & 61.0 & 3.3 & 7.5 & 8.3 & 0.09 & C3S1R 1 \\
\hline 50. & BanbhnioBheel & 76.2 & 4.8 & 7.7 & 6.0 & -0.45 & C3S1R1 \\
\hline 51. & Thario Halepota & 61.0 & 3.9 & 8.0 & 6.6 & 3.43 & $\mathrm{C} 3 \mathrm{~S} 1 \mathrm{R} 2$ \\
\hline 52. & Dharam & 21.3 & 4.4 & 8.3 & 9.1 & 4.72 & $\mathrm{C} 3 \mathrm{~S} 1 \mathrm{R} 2$ \\
\hline 53. & Chunhar & 51.8 & 8.6 & 8.1 & 6.3 & 0.44 & C3S1R \\
\hline \multicolumn{2}{|r|}{ Minimum } & 18.3 & 0.3 & 7.3 & 4.2 & -7.08 & C1S1R1 \\
\hline \multicolumn{2}{|r|}{ Maximum } & 76.2 & 13.5 & 9.0 & 15.5 & 8.40 & $\mathrm{C} 3 \mathrm{~S} 2 \mathrm{R} 1$ \\
\hline \multicolumn{2}{|r|}{ Mean } & 49.2 & 4.9 & 8.1 & 7.4 & 0.74 & \\
\hline \multicolumn{2}{|r|}{ Mode } & 51.8 & $\tilde{\mathrm{N}}$ & 8.0 & $\tilde{\mathrm{N}}$ & 0.03 & C3S1R 1 \\
\hline \multicolumn{2}{|r|}{ STD } & 14.2 & 3.2 & 0.39 & 2.4 & 2.77 & \\
\hline & $\mathrm{CV}$ & 0.29 & 0.65 & 0.05 & 0.32 & 3.74 & \\
\hline
\end{tabular}




\subsection{Classification of Groundwater Samples}

Groundwater samples were classified (Table 4) in the different groups according to the suggestions [14], with number of sites including C1S1R1 (4), C1S2R1 (1), C1S2R2 (1), C2S1R1 (11), C2S1R3 (1), C2S2R2 (1), C3S1R1 (22), C3S1R2 (8), C3S1R3 (1), and C3S2R1 (3). Majority of samples fall in the category C3S1R1 that is saline hazardous, but SAR and RSC in useable limits. Only four samples were of the category C1S1R1 (Good quality water related to all parameters).

\subsection{Recommendation of Selected Plant Species}

Tolerance plants have decreased growth at higher concentration, but maintained at low salt concentration. Whereas salt-sensitive crop is affected by the low concentration of salt. The different plant species (Table 5) fall in the various categories, i.e. tolerant, moderately tolerant, moderately sensitive and sensitive.

TABLE 3. PERCENTAGE OF SAMPLES FALL ABOVE MEAN VALUE OF EC ${ }_{\mathrm{IW}}$, PH, SAR AND RSC

\begin{tabular}{|c|c|c|c|}
\hline Parameters & Mean Value & 20 & Number of Samples far above the Mean Value \\
\hline ECiw $\left(\mathrm{dS} \mathrm{m}^{-1}\right)$ & 4.90 & 11 & $38 \%$ \\
\hline $\mathrm{pH}$ & 8.06 & 29 & $29 \%$ \\
\hline SAR & 7.40 & 16 & $55 \%$ \\
\hline RSC & 0.74 & $30 \%$ \\
\hline
\end{tabular}

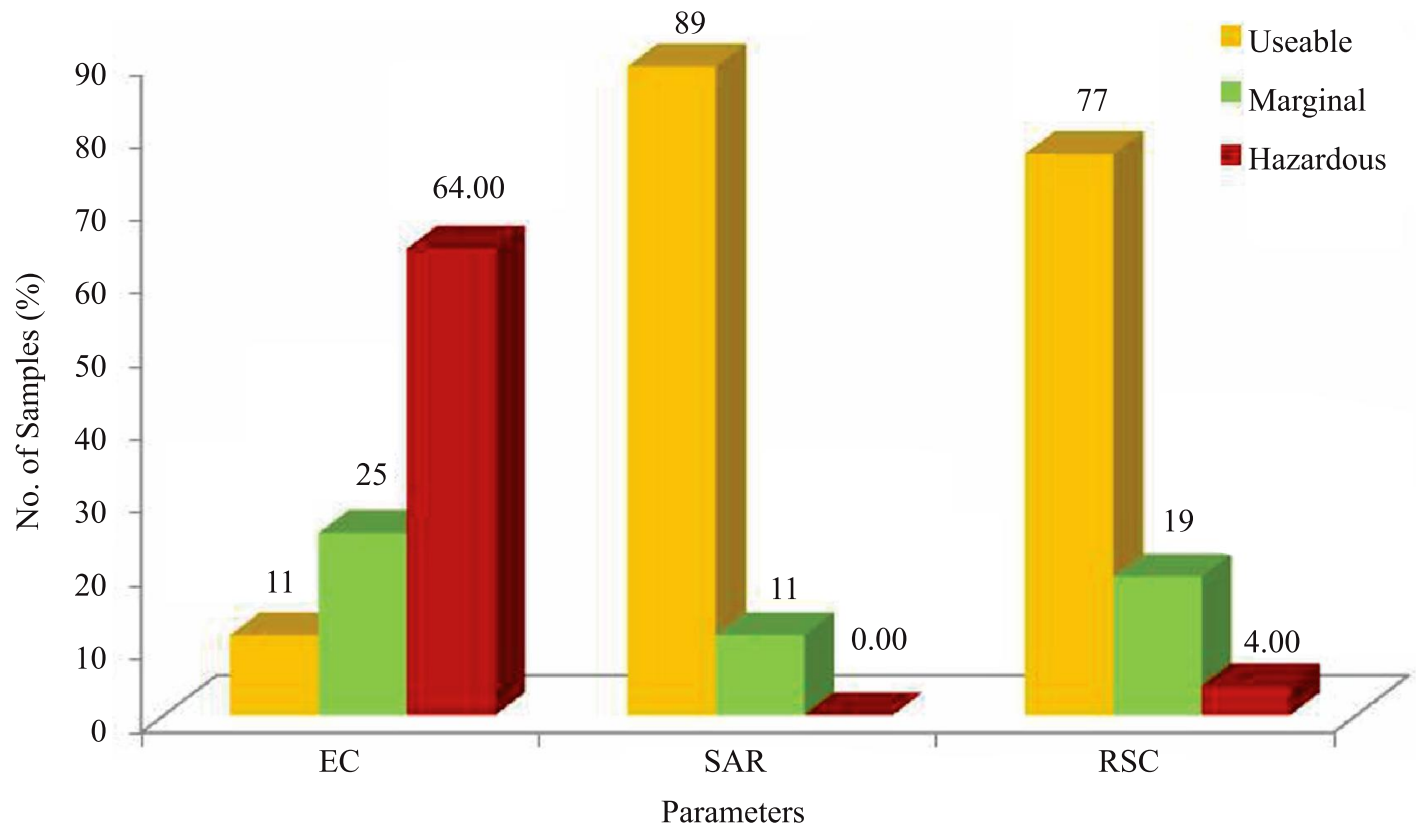

FIG 1. GROUNDWATER QUALITY OF TALUKA MITHI AND ISLAMKOT ON THE BASIS OF EC, SAR AND RSC 
TABLE 4. GROUNDWATER QUALITY CLASSES OF TALUKA MITHI AND ISLAMKOT

\begin{tabular}{|c|c|c|}
\hline Classes & No. of Samples & Sampling Site Numbers \\
\hline C1S1R1 & 4 & $24,29,30$ and 34 \\
\hline C1S2R1 & 1 & 28 \\
\hline C1S2R2 & 1 & $5,10,26,32,33,35,38,39,40,44$ and 48 \\
\hline C2S1R1 & 11 & 43 \\
\hline C2S1R3 & 1 & 47 \\
\hline C2S2R2 & 1 & $1,2,3,4,6,8,9,11,12,13,15,16,17,20,21,22,37,41,42,49,50$ and 53 \\
\hline C3S1R1 & 22 & $7,18,25,36,45,46,51$ and 52 \\
\hline C3S1R2 & 8 & 23 \\
\hline C3S1R3 & 1 & 1927 and 31 \\
\hline C3S2R1 & 3 & 74 \\
\hline
\end{tabular}

TABLE 5. SELECTED SALT-TOLERANT PLANT SPECIES GROWN UNDER DIFFERENT SALINE WATER ENVIRONMENT [14]

\begin{tabular}{|c|c|c|}
\hline Plant Categories & Water Quality Criteria & Plant Species \\
\hline Tolerant & Hazardous & Barley, cotton, date palm \\
\hline Moderately Tolerant & Marginal & Guar, jujube, sorghum \\
\hline Moderately Sensitive & $\begin{array}{c}\text { (Marginal) } \\
\text { Just above useable }\end{array}$ & $\begin{array}{c}\text { Cucumber, egg-plant, musk melon, radish, Spinach, water melon, } \\
\text { pearl millet, mung bean }\end{array}$ \\
\hline Sensitive & Useable & Carrot, lemon, onion, sesame \\
\hline
\end{tabular}

\section{CONCLUSION}

Quality of groundwater should be suggested periodically, because the properties of water changes time by time. Our results reveal that the water samples vary from useable, marginal and hazardous quality as per salinity $\mathrm{EC}_{\mathrm{iw}}$ and RSC values. However, almost all groundwater samples fall in two categories useable and marginal as of SAR values, whereas no one sample had sodium hazardous for irrigation. There were presence of major cations and anions sequences in groundwater $\mathrm{Na}^{+}>$ $\mathrm{Mg}^{2+}>\mathrm{Ca}^{2+}$ and $\mathrm{Cl}>\mathrm{HCO}_{3}>\mathrm{CO}_{3}^{2-}$. The samples were slightly alkaline to highly alkaline $\mathrm{pH}$ in nature. All water samples were classified into different groups and each group consisted of number of samples like 4, 1, 1, 11, 1, 1,
22, 8, 1 and 3 in separate group C1S1R1, C1S2R1, C1S2R2, C2S1R1, C2S1R3, C2S2R2, C3S1R1, C3S1R2, C3S1R3 and C3S2R1, respectively. In crux, we report that salinity, and not sodicity, was the major threat to the area under irrigation through these water bodies. Hence, we suggest the use of saline-tolerant crop and their genotypes in these areas for sustainable crop production.

\section{ACKNOWLEDGEMENTS}

This study is the part of Ph.D. dissertation research of first author sponsored by Higher Education Commission (HEC) of Pakistan under "HEC Indigenous Ph.D. Fellowship Program”. 


\section{REFERENCES}

[1] Beltran, J.M., "Irrigation with Saline Water: Benefits and Environmental Impact", Agricultural Water Management, Volume 40, No. 2, pp. 183-194, 1999.

[2] Rowell, D.L., "The Preparation of Saturation Extracts and the Analysis of Soil Salinity and Sodicity", Soil Science Methods and Applications", Longman Group., UK, 1994.
Barlow, P.M., "Ground Water in Fresh Water-Salt Water Environments of the Atlantic", Geological Survey, 2003.

Brady, N.C., and Weil, R.R., "The Nature and Properties of Soil”, 12th Edition,Prentice-Hall Inc., Upper Saddle River, New Jersey, 1999.

Khemani, P.K., Khatri, K.L., Jamro G.M., and Rajpar, I., "Quality of Irrigation and Drinking Water in Nangarparkar Region of Thar Desert of Pakistan", International Journal of Physical Sciences, Volume 7, No. 29, pp. 5118-5126, 2012.

Sial, N.B., Rajpar, I., Mangio, H.R., and Suthar, J.K., "Assessing Irrigation Quality of Well Water in Thar Desert (Pakistan)", Pakistan Journal of Agriculture, Agricultural Engineering \& Veterinary Sciences, Volume19, No. 2, pp. 8-10, 2003.

Nazir, A., "Ground Water Resources of Pakistan", Ripon Press Ltd. Lahore, Pakistan, 1974.

Al-Naeem, A.A., "Evaluation of Groundwater of AlHassa Oasis, Eastern Region Saudi Arabia”, Research Journal of Environmental Sciences, Volume 5, No. 7, pp. $624,2011$.

Tanninen, J., Kamppinen, L., and Nystrom, M., “PreTreatment and Hybrid Processes: NanofiltrationPrinciples and Application", Advanced Technology Publisher, Volume 13, pp. 978-1, London, 2005.

Estefan, G., Sommer, R., and Ryan, J., "Methods of Soil, Plant, and Water Analysis: AManual for the West Asia and North Africa Region", International Center for Agricultural Research in the Dry Areas, Volume 143, Beirut, Lebanon, 2013.
[11] Jaiswal, P.C., "Soil, Plant and Water Analysis", Kalyani Publishers, 2011.

[12] Richards, L.A., "Diagnosis and Improvement of Saline and Alkali Soils", US Department of Agriculture, Washington, 1969.

[13] Eaton, F.M., "Significance of Carbonates in Irrigation Waters", Soil Science, Volume 69, No. 2, pp. 123-134, 1950 .

[14] Qureshi, R.H., and Barrett-Lennard, E.G., "Saline Agriculture for Irrigated Land in Pakistan: AHandbook, Australian Centre for International Agricultural Research, 1998.

[15] Shelly, G.B., Cashman, T.J., and Quasney, J.J., "Microsoft Office Excel 2007", Comprehensive Concepts and Techniques, Cengage Learning, 2007.

[16] Ayers, R.S., and Westcot, D.W., "Water Quality for Agriculture", FAO Irrigation and Drainage Paper 29 Rev. 1, Food and Agricultural Organization, Rome, Volume 1, pp. 74, 1985.

[17] Wilde, F.D., Radtke, D.B., Gibs, J., Iwatsubo, R.T., "National Field Manual for the Collection of WaterQuality Data", US Geological Survey Techniques of Water-Resources Investigations, Book 9, A-6, 1998.

[18] Jalali, M., and Merrikhpour, H., "Effects of Poor Quality irrigation Waters on the Nutrient Leaching and Groundwater Quality from Sandy Soil”, Environmental Geology, Volume 53, No. 6, pp. 1289-1298, 2008.

[19] Nishanthiny, S.C., Thushyanthy, M., Barathithasan, T., and Saravanan, S., "Irrigation Water Quality Based on Hydro Chemical Analysis, Jaffna, Sri Lanka”, AmericanEurasian Journal Agriciculture \& Environmental Science, Volume 7, No. 1, pp. 100-102, 2010.

[20] Sagar, T.V., "Water Quality of Some Polluted Lakes in GHMC Area, Hyderabad-India”, Methodology, Volume 6, pp. 60-80. 
[21] Al-Tabbal, J.A., and Al-Zboon, K.K., "Suitability Assessment of Groundwater for Irrigation and Drinking Purpose in the Northern Region of Jordan", Journal of Environmental Science and Technology, Volume 5, No. 5, pp. 274-290, 2012.
[22] Singh, S., Raju, N.J., and Ramakrishna, C., "Evaluation of Groundwater Quality and Its Suitability for Domestic and Irrigation Use in Parts of the Chandauli-Varanasi Region, Uttar Pradesh, India”, Journal of Water Resource and Protection, Volume 7, No. 7, pp. 572, 2015. 